\title{
Accommodation space indicates dune development potential along an urbanized and frequently nourished coastline
}

\author{
Corjan Nolet and Michel J. P. M. Riksen \\ Soil Physics and Land Management Group, Wageningen University, P.O. Box 47, \\ 6700 AA Wageningen, the Netherlands \\ Correspondence: Corjan Nolet (corjan.nolet@gmail.com) \\ Received: 26 April 2018 - Discussion started: 14 May 2018 \\ Revised: 11 December 2018 - Accepted: 12 December 2018 - Published: 29 January 2019
}

\begin{abstract}
With densely populated areas well below mean sea level, the Netherlands relies heavily on its dunes to ensure coastal safety. About half of the sandy coastline, however, is subject to structural marine erosion and requires frequent sand nourishment as a counteractive measure. A key component of present-day coastal safety policy is creating favorable conditions for natural dune development. These conditions essentially involve (1) a steady supply of wind-blown sand towards (2) a wide accommodation space where sand can accumulate and dunes are sheltered from frequent storm surge impacts. This paper examines to what extent an experimental mega-scale beach nourishment (termed Zandmotor in Dutch) has contributed to creating accommodation space favorable for dune development. Using publicly available airborne lidar data and Sentinel-2 satellite imagery, favorable accommodation space is identified by comparing recent changes in coastal morphology against dune vegetation-cover dynamics. With a focus on European marram grass (Ammophila arenaria) as the most prominent dune-building species, this paper demonstrates that the Zandmotor supports an especially high potential for incipient (embryo) dunes to develop as most of its favorable accommodation space is located on the beach. However, considering the conditions required for successful marram grass establishment as well as persistent anthropogenic disturbances arising from recreation and nature management practices, it is not likely that dune development along this urbanized coastline reaches its full potential.
\end{abstract}

Vegetated coastal foredunes, the most seaward facing dune ridge parallel to the coastline, often form the first and foremost line of flood defense against the sea (Hardisty, 1994). This is certainly true for the Netherlands, a country where the most densely populated areas are situated well below mean sea level. And, although widely known for its hydraulic engineering structures, over $75 \%$ of the Dutch coastline relies on its foredunes to ensure coastal safety (Van Koningsveld and Mulder, 2004). About half of that sandy coastline, however, is subject to structural marine erosion and requires frequent nourishment of dredged-up sand as a counteractive measure (Van der Wal, 2004). Subsequently, while the foredunes in the Netherlands are considered natural landscape elements, they are so strongly modified by human intervention that they too could be considered a feat of hydraulic engineering (De Vriend et al., 2015).

The focus of Dutch coastal policy has traditionally been on safety from flooding, which was guaranteed by large structures such as sea dikes, groins and other artificial barriers. Nowadays, however, the focus has widened to also include preserving the spatial quality and natural values of the coastal zone (Van Slobbe et al., 2013). It was recognized that coastal dunes, apart from flood defense, also represent unique ecological and recreational values and often serve as an important source for drinking water supply (e.g., De Jong et al., 2014; Keijsers et al., 2015b). By acknowledging sand as "the carrier of all coastal functions" the principal management practice since 1990 has been to nourish the coastline with 
sand whenever it was about to retreat beyond a defined reference position (Van Koningsveld et al., 2007). A key component of such a dynamic preservation of the coastline involves utilizing natural processes to further redistribute the sand. By allowing marine and aeolian forces to gradually help shape the coastline, the aim of this building-with-nature engineering strategy is to counteract a negative sediment balance while minimizing adverse effects to the coastal ecosystem (Van Slobbe et al., 2013).

An essential element to building with nature in the Netherlands is the utilization of European marram grass ( $\mathrm{Am}$ mophila arenaria) to help stabilize and build up the foredunes (Keijsers et al., 2015b). Compared to other (native) coastal pioneer psammophytes that thrive on sandy soils, this beach grass is most effective at dune building because not only can it trap high amounts of wind-blown sand in its leaves and roots, but it will in fact grow much more vigorously because of regular burial in sand (e.g., Disraeli, 1984; Van der Putten et al., 1988; Hesp, 1991; Nolet et al., 2017). This introduces a reinforcing feedback crucial to coastal dune development: trapping of wind-blown sand encourages marram grass to grow, which in turn enhances the capacity of marram grass to trap sand and build dunes (Maun, 1998; Zarnetske et al., 2012). This trait, combined with the ability of clonal growth through rhizome fragments (Konlechner et al., 2013), enables marram grass to help create and maintain high vegetated foredunes critical to coastal safety (Ranwell, 1972; Keijsers et al., 2015b). Moreover, because the Dutch shoreline is frequently nourished with dredged-up sand, positive plant-sand feedback dynamics enable the adjacent foredunes to grow in pace with sea-level rise due to changes in the global climate (Temmerman et al., 2013).

For that reason, present-day Dutch coastal safety policy in particular prioritizes creating favorable conditions for natural dune development. These conditions, essentially, involve (1) a steady supply of wind-blown sand towards (2) a wide accommodation space (Jervey, 1988) where sand has the potential to accumulate and developing dunes are sheltered from frequent storm surge impacts (e.g., Ruggiero et al., 2001; Claudino-Sales et al., 2008; Montreuil et al., 2013; Van Puijenbroek et al., 2017a). Although a predominantly landward wind regime is required, the morphology of the beach arguably exerts the largest control on foredune development conditions (Short and Hesp, 1982). Aeolian sand supply, for example, is typically highest on gently sloping (i.e., dissipative) beaches, where wide intertidal areas store large volumes of sand that are well sorted by wave action (e.g., Hesp, 1989; Anthony, 2013). Wide accommodation space for foredune development is subsequently provided when such a dissipative coastline is supported by a wide supratidal beach that is high enough to offer protection from frequent storm surge impacts (e.g., Sallenger Jr., 2000; Suanez et al., 2012; Houser et al., 2008). Foredune development is initiated when discrete clumps of incipient dunes (i.e., embryo dunes) form after marram grass establishes it- self on the beach through dispersal of seeds and rhizome fragments by wind and water (Konlechner and Hilton, 2009; Hilton and Konlechner, 2011). Over time, and under the right conditions, these individual embryo dunes can merge into continuous and shore-parallel foredune ridges that extend in a seaward direction (Hardisty, 1994; Hesp, 1989, 2002).

Creating favorable conditions for dune development is an important goal for the Zandmotor (Dutch for "sand motor", see Fig. 1), an unprecedented mega-scale beach nourishment of $21.5 \mathrm{Mm}^{3}$ constructed in 2011 just south of The Hague (Stive et al., 2013). The overall purpose of this meganourishment experiment is to test whether its benefits in terms if coastal safety, spatial quality and natural values outweigh the extra costs involved and to determine to what extent such an approach can help cope with expected changes in the global climate (e.g., Mulder and Tonnon, 2011; Stive et al., 2013; De Schipper et al., 2016). In line with the building-with-nature approach, natural dynamics are encouraged to redistribute the sand of the Zandmotor along the coastline, thereby broadening the adjacent foredunes and beach. Specifically, the main objective of the project was defined as "Encouraging natural dune growth, primarily in width, in the coastal cell between the cities Rotterdam and The Hague. This creates a larger sand buffer to cope with rising sea level as well as more space for nature and recreation and a larger freshwater lens under the dunes" (Fiselier, 2010; Van Slobbe et al., 2013).

However, while the Delfland coast partly maintains relatively wide and natural dune areas, the aerial photos in Fig. 1 clearly show that in some places the dunes are not more than a narrow foredune ridge that is directly bordered by urban areas. Because the region is densely populated, the coastline (including the Zandmotor) faces persistent pressure from anthropogenic disturbances. Even though the Delfland coast is meant to serve a wide range of socioeconomic functions related to recreation and leisure, activities arising from these function are often in direct conflict with the objectives related to coastal safety and natural values (e.g., Jackson and Nordstrom, 2011; Lithgow et al., 2013). Within this context, this paper examines to what extent the Zandmotor has contributed to creating accommodation space favorable for dune development, i.e., accommodation space that is sheltered from frequent storm impacts and experiencing a steady accumulation of wind-blown sand. This favorable accommodation space is identified, using publicly available remote-sensing data, by (1) comparing the presence of existing dunes against recent morphology of the Delfland coast and by (2) comparing recent coastal morphological changes against changes in dune cover by marram grass. Then, by taking into account the existing dunes and the conditions required for successful marram grass establishment, the identified favorable accommodation space is used to indicate the full potential for dune development along this urbanized and frequently nourished coastline. 


\section{Materials and methods}

\subsection{Regional setting}

The Zandmotor is located along the Delfland coast, an approximately $15 \mathrm{~km}$ long stretch of coastline that runs between Rotterdam and The Hague parallel to the dominant southwestern wind direction. The Delfland coast has a long history of coastal erosion: early 17 th century maps make it clear that the coastline, compared with today, experienced a significant $(>1.5 \mathrm{~km}$ ) landward retreat (Van der Meulen et al., 2014). In the late 19th century the Delfland coast was fortified by groynes, but that only slowed down coastal erosion to a landward retreat of about $1 \mathrm{~m} \mathrm{yr}^{-1}$ on average. Therefore from the early 1980s onward, well before it became central policy, the Delfland coast has been frequently replenished with sand nourishment of varying volumes (Van Koningsveld et al., 2007). Still, in 2002 the Delfland coast was labeled a "weak link" as it did not meet stricter coastal safety standards that reflected expected increases in storm surge frequency and magnitude due to climate change (Keijsers et al., 2015b). Between 2009 and 2011, to guarantee that the Delfland coast could withstand hydraulic boundary conditions with a recurrence period of once every 10000 years, most of the existing foredunes were broadened in a seaward direction (up to about $100 \mathrm{~m}$ ) with a sand nourishment of approximately $20 \mathrm{Mm}^{3}$ over a length of $12 \mathrm{~km}$. This included construction of a new dune area in the south (called Spanjaardsduin in Dutch) to compensate for loss of natural values because of expansion of the Rotterdam harbor (Van der Meulen et al., 2014). After completion, the newly created foredune ridge ranged between 4 and $12 \mathrm{~m}$ above mean sea level (a.m.s.l.) from toe to crest. For stabilization, the approximately $15^{\circ}$ stoss slope was manually planted with shoots of marram grass in a regular pattern of about 7-9 small tussocks per square meter. About $75 \%$ of the Delfland coastline has been reinforced in this manner between 2009 and 2011. The newly created foredune ridge stretches landward approximately until the paved bike path (gray line in Fig. 1) that runs along its crest.

Once the new safety standards were met, the Delfland coast was considered an appropriate location to conduct the Zandmotor mega-nourishment experiment. As can be seen in Fig. 1, the Zandmotor has a hook-shaped design that aims to mirror the natural onshore migration of an intertidal sandbar. Just after construction it had a surface area of about 28 ha, extending $2.5 \mathrm{~km}$ along the coastline and protruding $1 \mathrm{~km}$ into the sea. Natural processes have since then been working to redistribute the sand, causing the base to flatten and the sand to spread in alongshore directions (De Schipper et al., 2016). Based on an empirical relation between beach width and dune foot migration, a preliminary modeling study estimated that after 20 years the Zandmotor would broaden the dunes along the Delfland coast by about 33 ha (Mulder and Tonnon, 2011). A distinct feature that sets the Zandmotor apart from more traditionally nourished or natural coastlines is the locally very high construction height. Most of the base is constructed at a height of around $5 \mathrm{~m}$ a.m.s.l., while just north of a small dune lake the Zandmotor reaches a height of $7 \mathrm{~m}$ a.m.s.l. This is well above the current maximum storm surge level of about $3 \mathrm{~m}$ a.m.s.l., so reworking of sand on the Zandmotor is almost exclusively due to aeolian forcing (Hoonhout and De Vries, 2017). As a consequence, while beneficial to already established dunes, Puijenbroek (2017) concluded that this high construction height may also impede the establishment of new embryo dunes as rhizome dispersal by tide and wave action is absent on parts of the Zandmotor. The semidiurnal tidal dynamics along the Delfland coast are characterized by a spring (neap) tidal amplitude around $2.0 \mathrm{~m}$ $(1.5 \mathrm{~m})$, generating alongshore currents with a velocity of up to $0.5 \mathrm{~ms}^{-1}$ (Luijendijk et al., 2017).

\subsection{Vegetated coastal dune dynamics}

Data on the presence of dunes along the Delfland coast and changes in dune cover by marram grass were obtained using Sentinel-2A multispectral satellite imagery provided by the European Space Agency (ESA). Sentinel-2 images are acquired in 13 spectral bands in the visible (VIS), near-infrared (NIR) and shortwave infrared (SWIR) spectral ranges. Two level-1C images were downloaded from the Copernicus open-access hub (https://scihub.copernicus.eu, last access: 11 January 2018), with acquisition dates in the autumn of 2016 (11 September) and 2017 (12 October), when aboveground biomass of marram grass is highest (Nolet et al., 2017). With applied radiometric calibration and geometric correction, level 1C images contain top of atmosphere (TOA) reflectance in cartographic geometry (Drusch et al., 2012). Out of the 13 available bands, the 4 bands with the highest spatial resolution ( $10 \mathrm{~m}$ pixel size) were selected for further analysis. Table 1 lists the characteristics of the bands, which are in the visible (blue, green, red) and near-infrared part of the spectrum. To illustrate the Sentinel-2 imagery used for analysis, Fig. 2 shows an image of the Zandmotor indicating the Normalized Difference Vegetation Index (NDVI; Rouse Jr. et al., 1974; Tucker, 1979). This ratio takes advantage of the contrasting reflection of photosynthetically active vegetation at visible and near-infrared wavelengths and is widely used for detection and classification of vegetated areas (e.g., Pettorelli et al., 2005; Nolet et al., 2017).

\subsubsection{Linear spectral unmixing}

The four selected bands were stacked into a new multispectral data cube and a linear spectral unmixing procedure was applied. This was done to derive sub-pixel proportions of dune cover by marram grass, the most prominent and abundant dune-building species. Linear spectral unmixing is an approach to determine the relative abundance of userspecified ground cover components (endmembers) in multispectral (or hyperspectral) imagery based on its spectral char- 
(a)

Sand motor
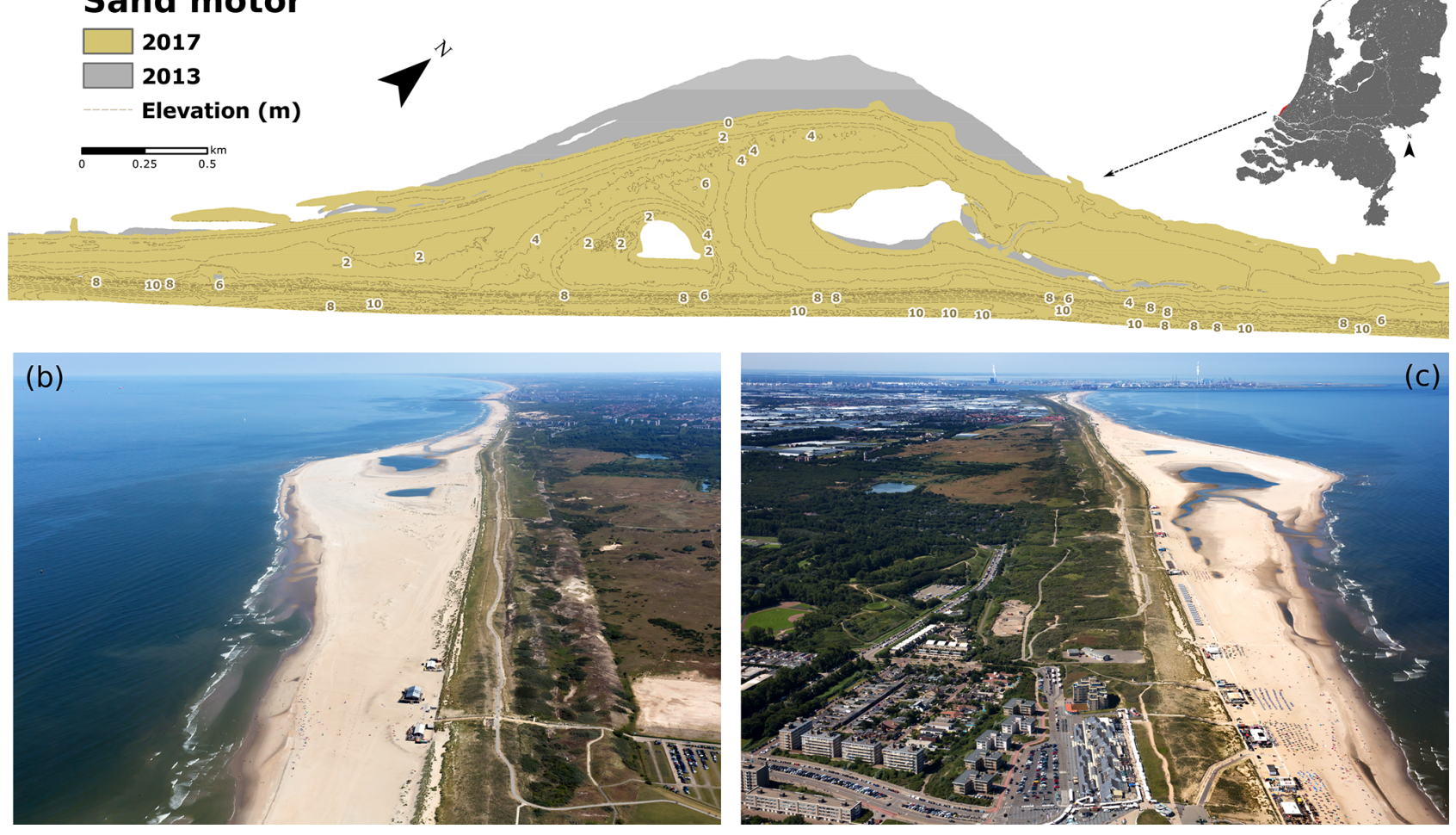

Figure 1. The Zandmotor ("sand motor"), an experimental mega-scale beach nourishment located along the Delfland coast, the Netherlands. (a) The design of the Zandmotor mirrors the onshore migration of an (intertidal) sandbar and aims to provide coastal safety by redistributing its sand along the coastline, thereby broadening the beach and dunes. (b-c) Aerial photographs of the Zandmotor and Delfland coast taken on 9 July 2017, facing north (b) towards The Hague and south (c) towards the harbor of Rotterdam. The Delfland coast maintains relatively wide and natural dune areas, but in some places the dunes are no more than a narrow foredune ridge directly bordered by urbanized areas.

Table 1. Sentinel-2A bands in VIS and NIR used for linear spectral unmixing procedure.

\begin{tabular}{lccc}
\hline Band & $\begin{array}{c}\text { Central } \\
\text { wavelength }(\mathrm{nm})\end{array}$ & $\begin{array}{c}\text { Bandwidth } \\
(\mathrm{nm})\end{array}$ & $\begin{array}{c}\text { Pixel } \\
\text { size }(\mathrm{m})\end{array}$ \\
\hline 2-Blue & 496.6 & 98 & 10 \\
3- Green & 560.0 & 45 & 10 \\
$4-$ Red & 664.5 & 38 & 10 \\
$8-$ NIR & 835.1 & 145 & 10 \\
\hline
\end{tabular}

acteristics (e.g., Smith et al., 1985; Settle and Drake, 1993; Theseira et al., 2003). It has successfully been applied before by Lucas et al. (2002) and Zhang and Baas (2012) in mapping the abundance of vegetation, including marram grass, in coastal dune environments. The reflectance at each pixel of the image is assumed to be a linear combination of the reflectance of the endmembers present within the pixel:

$R_{i}=\sum_{k=1}^{n}\left(f_{k} R_{i k}\right)+e_{i}$

where $i=1, \ldots, m$ are the number of spectral bands, $R_{i}$ is the reflectance of band $i$ of each pixel, $k=1, \ldots, n$ are the number of endmembers, $f_{k}$ is the proportion of endmember $k$ within each pixel, $R_{i k}$ the spectral reflectance of endmember $k$ within each pixel on band $i$, and $e_{i}$ is the residual error term (Lu et al., 2003). Here, two endmembers were specified (see Fig. 2). The first endmember was made up by a group of pixels ( eight) containing only beach sand, the second endmember by a similarly sized group of pixels fully covered by marram grass. The spectra of the two endmembers were obtained for each Sentinel-2 image separately, and maps containing subpixel proportions of beach sand and marram grass were derived using ENVI version 4.8 (Exelis Visual Information Solutions, Boulder, Colorado). The subpixel proportions of marram grass were subsequently interpreted as a percentage dune cover within each $10 \mathrm{~m}$ pixel. Older established dunes (with NDVI $>0.6$ in Fig. 2) were excluded from the analysis as they are minimally exposed to marine forces and mostly covered with vegetation species other than marram grass. Further, all artificial structures on the beach related to coastal safety (e.g., groynes) and leisure and recreation were masked from the imagery before the linear spectral unmixing procedure was executed.

Changes in dune cover by marram grass along the Delfland coast were obtained by subtracting the percentages of dune 


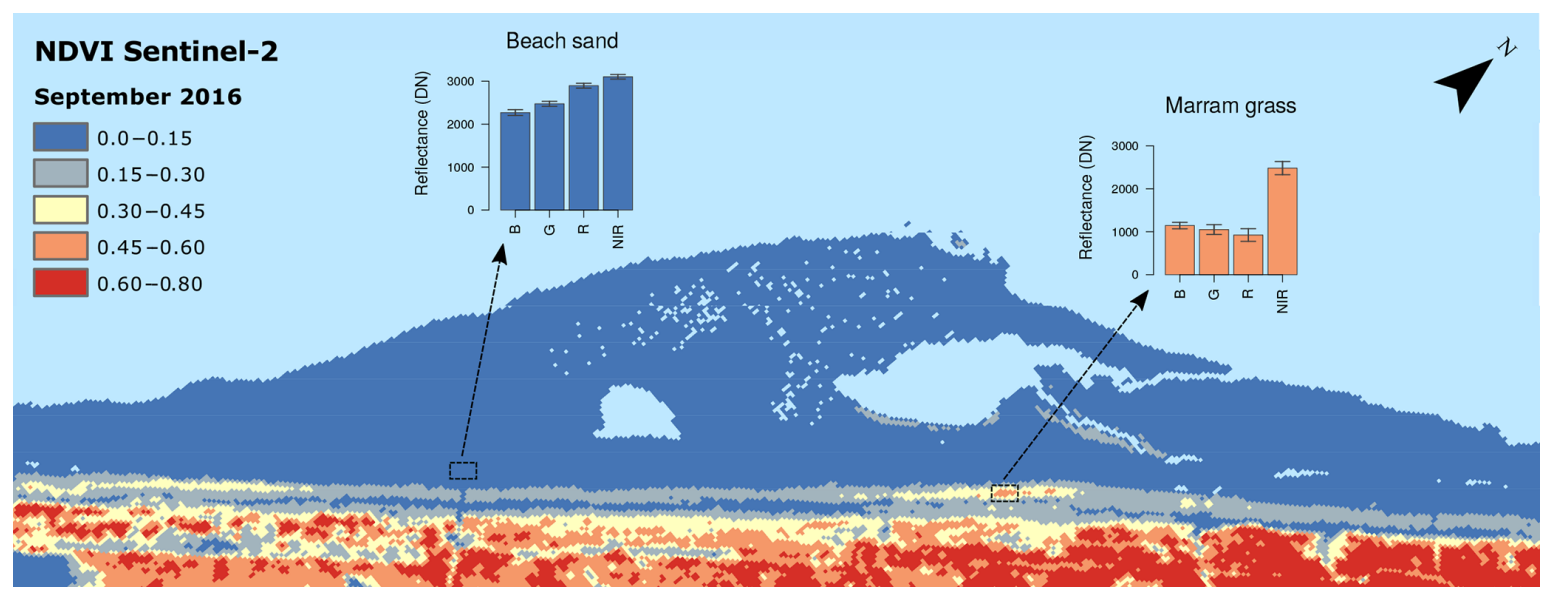

Figure 2. Map of the Zandmotor indicating Normalized Difference Vegetation Index (NDVI), and to illustrate the Sentinel-2 imagery and selection of endmembers (user-specified ground cover components) for the linear spectral unmixing procedure. Subpixel proportions of beach sand and marram grass (for every $10 \mathrm{~m}$ pixel) were derived using endmember reflectance spectra for four bands in the visible and near-infrared spectral ranges.

cover calculated for the 2016 Sentinel-2 image from the snapshot of 2017. Changes in dune cover between 2016 and 2017 were expressed for every $10 \mathrm{~m}$ pixel but also as an alongshore change in cover area $\left(\mathrm{m}^{2} \mathrm{~m}^{-1} \mathrm{yr}^{-1}\right)$. This was done for better interpretation of dune dynamics along the Delfland coast and was calculated by multiplying the surface area of each pixel $\left(100 \mathrm{~m}^{2}\right)$ by its fractional cover change. The linear spectral unmixing procedure was validated against a high-resolution orthomosaic of a stretch of foredune directly adjacent to the Zandmotor (see also Fig. 3). The georeferenced orthomosaic ( $5 \mathrm{~cm}$ pixel size) was obtained by an unmanned aerial vehicle (UAV) during a flight on 1 September 2016, so 10 days before the acquisition date of the 2016 Sentinel-2 image. Using a $k$-means clustering algorithm (Hartigan and Wong, 1979), the individual $5 \mathrm{~cm}$ pixels of the orthomosaic were classified either as beach sand or marram grass. The accuracy of the algorithm was confirmed by visual inspection; for more details about acquisition and processing of the UAV-derived data the reader is referred to Nolet et al. (2017). The orthomosaic was subsequently resampled to match the $10 \mathrm{~m}$ pixel size resolution of the Sentinel-2 imagery and dune cover depicted in the orthomosaic was calculated as the proportion of the (former) $5 \mathrm{~cm}$ pixels classified as marram grass contained within each newly aggregated $10 \mathrm{~m}$ pixel.

\subsection{Coastal morphology}

Data on the morphology and morphological changes in the Delfland coast were obtained from digital terrain models (DTMs) provided by Rijkswaterstaat, the executive agency of the Ministry of Infrastructure and Water Management. The $2 \mathrm{~m}$ pixel size DTMs are produced every year (since 1996) for coastline monitoring purposes by airborne lidar and have been made public under a Creative Commons Zero (CC0) statement. The contractor responsible for the lidar flights guaranteed a minimum density resolution of 1 laser point per square meter, with a systemic vertical error equal to or less than $2.6 \mathrm{~cm}$ and standard deviation equal to or less than $\pm 2.0 \mathrm{~cm}$. Five yearly DTMs of the Delfland coast were used for analysis, acquired in spring 2013 until spring 2017. Changes in coastal morphology were first expressed by average change in height per year $\left(\mathrm{m} \mathrm{yr}^{-1}\right)$, which was calculated per consecutive time step: $t_{5-1}=\left(t_{2-1}+t_{3-2}+t_{4-3}+\right.$ $\left.t_{5-4}\right) / 4$. This was done to better consider temporal variations within each year and to account for yearly changes of the shoreline. Coastal morphological changes were also expressed as an average (alongshore) change in sand volume per year $\left(\mathrm{m}^{3} \mathrm{yr}^{-1}\right.$ or $\left.\mathrm{m}^{3} \mathrm{~m}^{-1} \mathrm{yr}^{-1}\right)$. Sand volume changes were likewise calculated per consecutive time step and obtained by multiplying the surface area of each pixel $\left(4 \mathrm{~m}^{2}\right)$ by its yearly change in height. The quality of the DTMs were verified by comparing the height of features along the coastline that remained unchanged between 2013 and 2017 (e.g., parking lots, paved roads, building rooftops). The average standard deviation of the vertical component of the five DTMs (using $\approx 100$ samples) was determined to be $\pm 2.4 \mathrm{~cm}$. Data are available at https://rijkswaterstaat.nl/apps/ geoservices/geodata/dmc (last access: 16 January 2018). The Delfland coast considered in the analysis covers a subaerial area of about 500 ha and extends in the landward direction until the older established dunes. This approximately coincides with the paved bike-path (gray line in Fig. 1) running along the crest of the newly created foredune ridge. In order to compare the morphology and morphological changes in the Delfland coast against the presence of dunes and changes in dune cover by marram grass, the $2 \mathrm{~m}$ resolution DTMs 


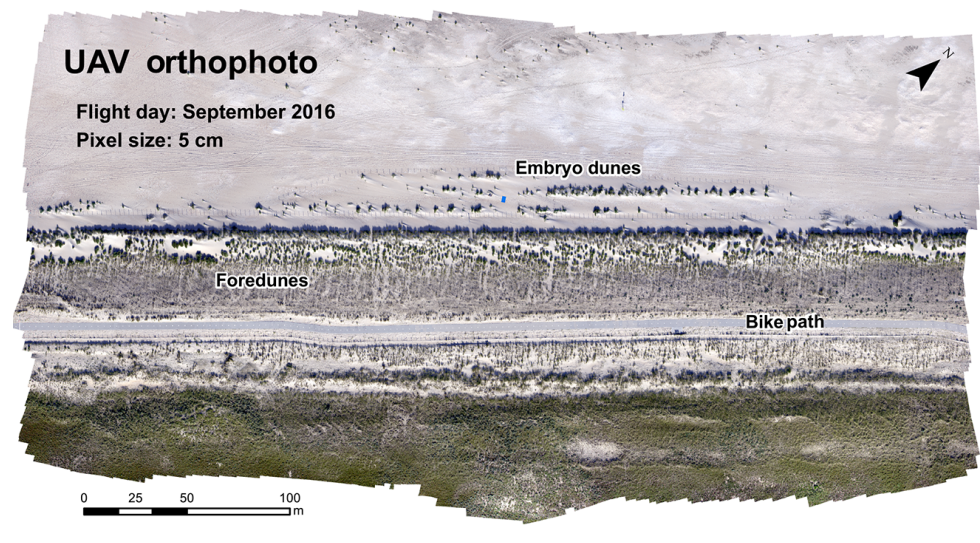

\section{Validation linear spectral unmixing}

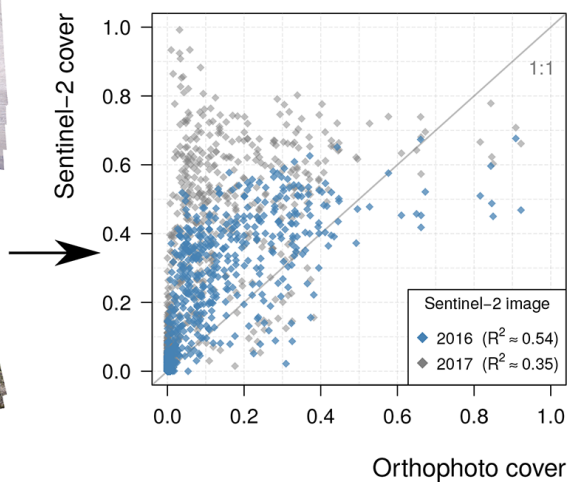

Figure 3. Validating the linear spectral unmixing procedure on the Sentinel-2 images using an orthophoto (5 $\mathrm{cm}$ pixel size) derived in September 2016 by an unmanned aerial vehicle (UAV). Linear spectral unmixing produces a systematic overestimation of subpixel proportions of marram grass cover compared to the cover values calculated from the orthophoto. A positive linear regression model explains $54 \%$ of the variance for the 2016 Sentinel- 2 image and $35 \%$ of the variance for the 2017 image.

were resampled using bilinear interpolation to match the $10 \mathrm{~m}$ pixel size of the Sentinel-2 imagery.

\section{Results}

Figure 3 shows the results of validating the linear spectral unmixing procedure on the Sentinel-2 images. The dune cover calculated from the orthophoto and the two Sentinel-2 images are plotted against each other in Fig. 3b. It is clear that deriving subpixel proportions of dune cover using linear spectral unmixing results in an overestimation of dune cover by marram grass. Even though $54 \%$ of the variance for the 2016 Sentinel-2 image can be explained by a positive linear regression model, most of the data points deviate from the $1: 1$ identity line because of higher dune cover values calculated by the Sentinel- 2 image. This trend, however, appears to be systematic to the linear spectral unmixing procedure since the data points from the 2017 Sentinel-2 image deviate even further from the identity line. This lower correlation $\left(R^{2} \approx 0.35\right)$ is in line with expectation as dune cover by marram grass was observed to have increased at this location between 2016 and 2017. So even though the linear spectral unmixing procedure overestimates the subpixel proportions of dune cover, the derived marram grass cover values for each Sentinel-2 image appear to be comparable relative to each other.

Figure 4 shows the derived maps used to identify favorable accommodation space for dune development. The first map (Fig. 4a) gives an overview of the morphological features, including the Zandmotor, during early spring 2017 . The beach ranges between 0 and $6 \mathrm{~m}$ a.m.s.l. in height and this is where new embryo dunes have either formed or expanded since 2011. The foredunes are exclusively covered by marram grass and stretch fully along the coastline, albeit at variable widths, at heights between $6-14 \mathrm{~m}$ a.m.s.l. This indicates that the toe of the foredunes, compared to their construction height in 2011, have been raised by about $2 \mathrm{~m}$ due to aeolian deposition. The second map (Fig. 4b) shows how the subaerial coastal morphology changed between 2013 and 2017, expressed by the average yearly change in height $\left(\mathrm{m} \mathrm{yr}^{-1}\right)$. It is clear that the most seaward part of the Zandmotor experienced strong erosion due to marine forcing, while most of the foredunes and particularly the beach just south and north of the Zandmotor experienced accretion due to sand-spreading effects. The base of the Zandmotor with its high construction height either remained relatively stable or experienced moderate erosion. These morphological dynamics are more distinctly reflected in Fig. 4c, which shows the average alongshore change in coastal sand volumes $\left(\mathrm{m}^{3} \mathrm{~m}^{-1} \mathrm{yr}^{-1}\right)$ between 2013 and 2017. On average, the Delfland coastline has been accretive, at a rate of $19.3 \mathrm{~m}^{3} \mathrm{~m}^{-1} \mathrm{yr}^{-1}$, but it is clear that there has been a high alongshore variability in sand accretion and erosion rates. This can be attributed to the anticipated behavior of the Zandmotor: the accretive areas on its flanks gained approximately $2.8 \times 10^{5} \mathrm{~m}^{3} \mathrm{yr}^{-1}$ of sand, while the erosive areas on its base lost about $1.7 \times 10^{5} \mathrm{~m}^{3} \mathrm{yr}^{-1}$ of sand. Further, the foredunes experienced accretion of sand at relatively stable alongshore rates. In total, at an average rate of $11 \mathrm{~m}^{3} \mathrm{~m}^{-1} \mathrm{yr}^{-1}$, the foredunes along the Delfland coast gained approximately $1.6 \times 10^{5} \mathrm{~m}^{3} \mathrm{yr}^{-1}$ of sand between 2013 and 2017.

The third map (Fig. 4d) shows how the dune cover by Marram grass (expressed as percentage per $10 \mathrm{~m}$ pixel) changed along the Delfland coast between the acquisition dates of the two Sentinel-2 images. Using changes in marram grass cover as a proxy for dune development potential, it appears that in most places the dunes along the coastline have been expanding over the course of a year. This observation, however, must be considered with some reservation, as observed changes in marram grass cover may also have been due to 


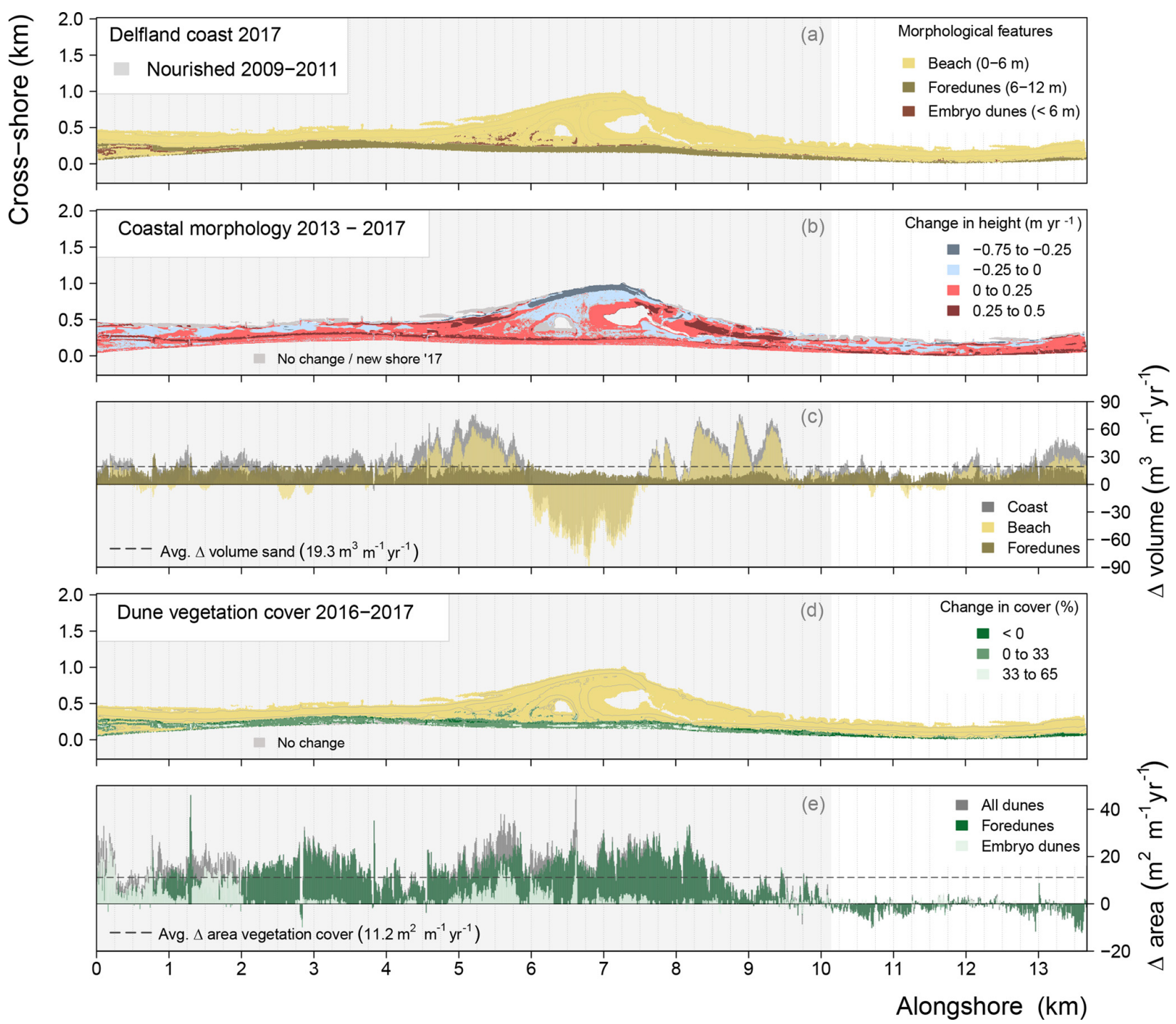

Figure 4. Morphological changes and dune vegetation-cover dynamics of the Delfland coast. (a) Map of the considered domain including the relevant morphological features (beach, foredunes, embryo dunes) in 2017. (b) Map of subaerial coastal morphological changes between 2013 and 2017, expressed average change in height per year $\left(\mathrm{m} \mathrm{yr}^{-1}\right)$. (c) Average alongshore changes in coastal sand volumes $\left(\mathrm{m}^{3} \mathrm{~m}^{-1} \mathrm{yr}^{-1}\right)$ between 2013 and 2017 for the Delfland coast and differentiated by the beach (embryo dunes included) and foredunes. (d) Map of changes in dune cover by marram grass between 2016 and 2017, expressed as percentage per $10 \mathrm{~m}$ pixel. (e) Alongshore changes in marram grass dune cover $\left(\mathrm{m}^{2} \mathrm{~m}^{-1} \mathrm{yr}^{-1}\right)$ between 2016 and 2017, with differentiation between the foredunes and embryo dunes.

denser or taller growth of marram grass and not because of actual lateral expansion. Having said that, Fig. 4d suggests that particularly the embryo dunes have been expanding, from 3 to 5 ha between 2016 and 2017. As a result, in 2017 about $17 \%$ of the dunes along the Delfland coast could be considered embryo dunes, of which most developed naturally along the coastline. The foredunes, in contrast, appear to have experienced more spatial variation in marram grass cover changes. Figure $4 d$ suggests that, along most of the Delfland coast, the foredunes have been expanding between 2016 and 2017. However, especially at the dune toe and just leeward of the dune crest, the foredunes appear to have declined somewhat in cover. This decline is most apparent north of the Zandmotor, which is clearly reflected in the second graph (Fig. 4e) that shows the alongshore yearly change in dune cover $\left(\mathrm{m}^{2} \mathrm{~m}^{-1} \mathrm{yr}^{-1}\right)$ between 2016 and 2017. This northerly foredune decline will be examined in more detail in the discussion, but it can likely be attributed to anthropogenic disturbances (due to recreational activities as well as nature management practices) and to the fact that this stretch of coastline has not been nourished with sand when the Delfland coast was reinforced between 2009 and 2011. All in all, data from Sentinel-2 imagery suggests that the dunes along the Delfland coast have been expanding between 

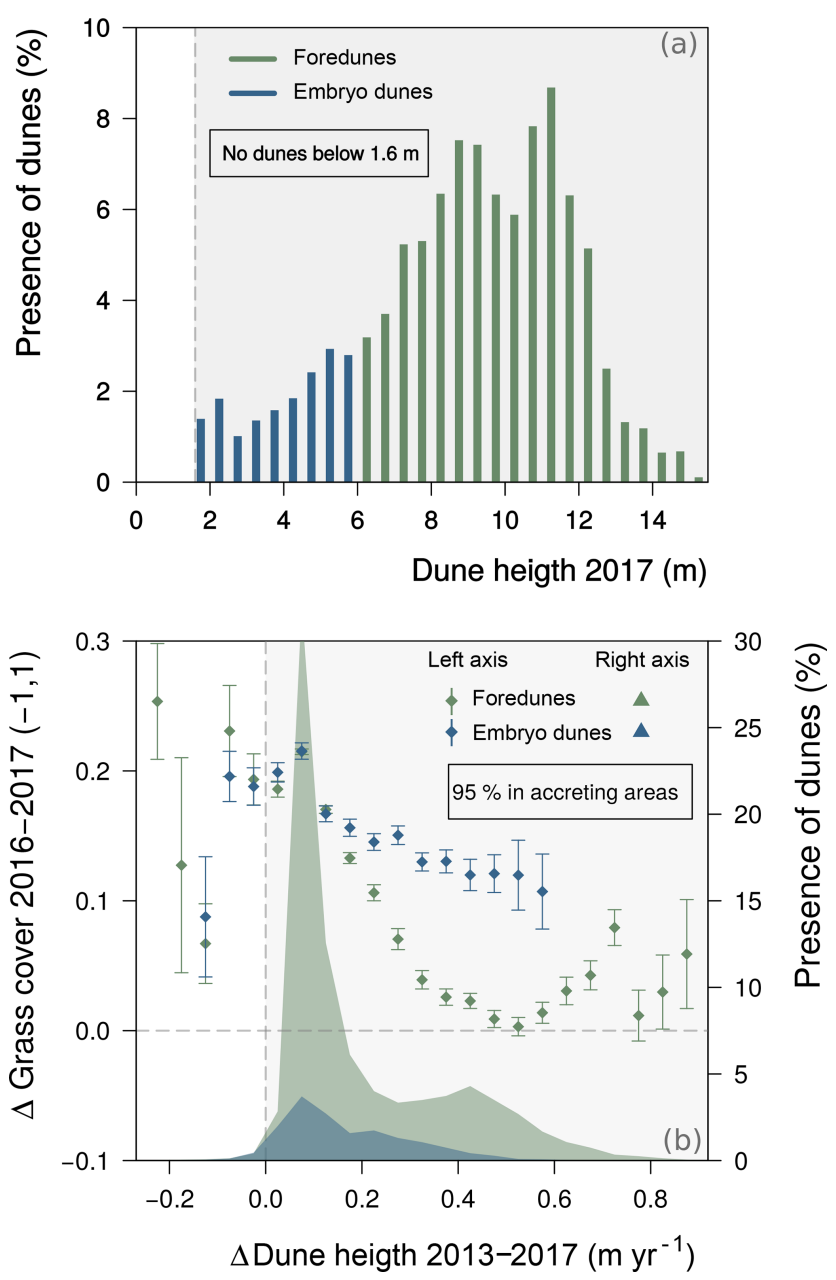

Figure 5. Identifying favorable accommodation space for dune development (both foredunes and embryo dunes) along the Delfland coast. (a) Comparing the presence of dunes in 2017 to its elevation: no dunes present below $1.6 \mathrm{~m}$ a.m.s.l. Comparing the changes in dune cover by marram grass from 2016 to 2017 to the average yearly change in dune height between 2013 and 2017: most dunes were present in accreting areas (right axis) and almost all dunes increased in cover by marram grass between 2016 and 2017 (left axis).

2016 and 2017 at an average rate of about $11.2 \mathrm{~m}^{2} \mathrm{~m}^{-1} \mathrm{yr}^{-1}$. For the foredunes, this amounted to an increase in dune cover of 42 to 54 ha. Although, as stated before, this may be an exaggerated number as increase in dune cover by marram grass has likely not been due to lateral growth alone.

Accommodation space is considered favorable for dune development when it is (1) sheltered from frequent storm impacts and (2) experiencing a steady accumulation of windblown sand. The first (boundary) condition is identified by comparing the presence of dunes along the Delfland coast in 2017 to the height at which they were located. As Fig. 5a demonstrates, in 2017 there were no dunes present below a height of $1.6 \mathrm{~m}$ a.m.s.l. All embryo dunes were located on the beach between 1.6 and $6 \mathrm{~m}$ a.m.s.l., while the foredunes were located at heights between 6 and $14 \mathrm{~m}$ a.m.s.l. This suggests, at least for 2017, that dunes along the Delfland coast were sheltered from storm impacts above a height of $1.6 \mathrm{~m}$ a.m.s.l. Accommodation space, as a result, is considered favorable for dune development above this boundary height. The second condition is identified (or verified as the positive effect of sand burial on marram grass vigor, which is well documented) by comparing the changes in dune cover by marram grass between 2016 and 2017 to the average yearly change in dune height between 2013 and 2017 (see Fig. 5b). Several observations can be drawn from that comparison but, most importantly, it demonstrates that $95 \%$ of all dunes along the Delfland coast in 2017 (both embryo dunes and foredunes) were present in areas that experienced on average a continuous accretion of sand from 2013 to 2017. This indicates that favorable accommodation space for dune development can indeed be characterized by a steady accumulation of sand. And since all dunes in 2017 were located above a height of $1.6 \mathrm{~m}$ a.m.s.l., it is reasonable to assume that this accumulation of sand occurred predominantly by aeolian forcing. In addition, Fig. $5 b$ shows that almost all dunes increased in cover by marram grass between 2016 and 2017. Overall this increase in cover was most pronounced for the embryo dunes, as the foredunes showed limited increase and even some decrease in dune cover towards higher changes in dune height. The largest increase in dune cover between 2016 and 2017, however, coincided with the same change in dune height $\left(\sim 0.1 \mathrm{~m} \mathrm{yr}^{-1}\right)$ for both the embryo dunes and the foredunes.

The identified accommodation space favorable for dune development (i.e., located above $1.6 \mathrm{~m}$ a.m.s.l. in height and experiencing a steady accumulation of wind-blown sand) is shown in Fig. 6a. Including the parts that were already covered by marram grass, it is clear that large areas along the Delfland coast were favorable for dune development in 2017. Especially the sheltered and accreting southern and middle part of the Zandmotor stood out for its large favorable accommodation space for dunes to develop. This is reflected more clearly by Fig. 6c, which shows the favorable accommodation space along the Delfland coast $\left(\right.$ in $^{2} \mathrm{~m}^{-1}$ ) as well as the potential for new dune development. As Fig. $6 \mathrm{~b}$ shows, this potential is calculated by subtracting the dune cover already present in 2017 from the total favorable accommodation space. Fig. $6 \mathrm{c}$ makes it clear that dune development potential along the Delfland coast is mainly reserved for embryo dune development, as most of the favorable accommodation space is located on the beach. Further, Fig. 6c highlights the overall importance of the Zandmotor for dune development along the Delfland coast; by providing the largest favorable accommodation space, the Zandmotor supports the highest potential for new dunes to develop. The existing foredunes show a limited development potential as they are already quite densely covered by marram grass. Still, of the considered 500 ha domain of the Delfland coast, in 2017 an 
estimated two-thirds ( $\sim 165 \mathrm{ha}$ ) appears to have provided favorable accommodation space for dunes to develop.

\section{Discussion}

This paper examined to what extent the Zandmotor has contributed to creating accommodation space favorable for dune development along the Delfland coast. The results indicate that the Zandmotor itself provides the most favorable accommodation space, for it has large areas located above $1.6 \mathrm{~m}$ a.m.s.l. that on average experience a continuous accretion by wind-blown sand. As such, the results highlight that the Zandmotor supports an especially high potential for new embryo dunes to develop as most of its accommodation space is located on the beach. This section examines the merit of the identified conditions for when accommodation space is considered favorable for dune development, as well as the merit of using favorable accommodation space to indicate dune development potential. The latter is examined in relation to the design and intended dynamical nature of the Zandmotor, the conditions required for successful establishment of marram grass and the persistent anthropogenic disturbances along the Delfland coast arising from recreation and nature management practices.

\subsection{Conditions indicating favorable accommodation space for dune development}

Accommodation space is considered favorable for dune development when it is sheltered from storm impacts and experiences a steady accumulation of wind-blown sand. The latter condition is not disputed, as the reinforcing feedback between the growth response of marram grass and burial by wind-blown sand is well documented (Huiskes, 1979; Disraeli, 1984; Maun and Lapierre, 1984; Van der Putten et al., 1988; Hesp, 1991; Maun, 1998) and recognized to be fundamental to coastal dune development in temperate regions around the world (e.g., Baas and Nield, 2010; Durán and Moore, 2013; Keijsers et al., 2016; Nolet et al., 2017). The positive feedback mechanism originates from a trait that all beach grasses of the genus Ammophila possess, namely potentially unlimited horizontal and vertical growth through its rhizomes (Gemmell et al., 1953; Ranwell, 1972). Whether marram grass grows horizontally or vertically subsequently depends on the amount of wind-blown sand, which makes it so particularly advantageous to dune building. After establishment, by seed or rhizome dispersal, marram grass first produces leafy shoots along newly developing horizontal rhizomes. When wind-blown sand is trapped by the leafy shoots, the immediate sand surface is raised and a small embryo dune is formed (Hesp, 1989). The leafy shoots are capable of growing up through a moderate thickness of sand by elongation of individual leaves. If, however, a leafy shoot is overwhelmed by sand deposition, one or more of its axillary buds develop into a vertical rhizome that will con- tinue to grow until the surface is reached. Adventitious roots are produced from the nodes of the vertical rhizome and the horizontal rhizomes gradually die, so that the vertical rhizomes become independent of one another. This process may be repeated as long as aeolian supply is abundant and marram grass continues to trap sand. The capacity to trap sand, as noted before, is enhanced by the growth response of marram grass to sand trapping, which introduces the positive feedback mechanism driving coastal dune development (Gemmell et al., 1953; Ranwell, 1972). Using very highresolution data, Nolet et al. (2017) showed that marram grass on foredunes along the Zandmotor appears to thrive best under a sand trapping rate of approximately $0.3 \mathrm{~m}$ of sand per growing season and that marram grass can withstand sand burial of up to $1 \mathrm{~m}$ of sand. However, while this demonstrates how positive plant-sand feedback steers dune development, it must be noted that the physical size of a developing dune and predominant wind regime also controls its morphology (Davidson-Arnott et al., 2018). As dunes grow, for example, a limit is imposed on its height because the wind force required to transport sand upslope increases significantly (e.g., Arens et al., 1995; Arens, 1996; Keijsers et al., 2015a). Coastal foredunes therefore tend to expand in width rather than height, which emphasizes the importance of the wide favorable accommodation space the Zandmotor provides for foredune development.

The condition that accommodation space is considered favorable when it is sheltered from storm impacts warrants closer inspection, because the impacts of a storm surge depend both on the magnitude of the storm as well as the geometry of the beach (Houser et al., 2008). Wind stress due to atmospheric pressure differences drive storm surge levels and offshore wave conditions, but the vertical dimension of the beach profile, in particular, exerts great control on shoreline parameters such as wave setup, swash and run-up (e.g., Stockdon et al., 2006; Sallenger Jr., 2000; Ruggiero et al., 2001). This is significant because the dissipation of kinetic energy of breaking waves is responsible for the highest rates of coastal erosion and dune decline (e.g., Vellinga, 1982; Short and Hesp, 1982). However, while empirical models can calculate wave run-up levels and wave breaking energy from parameters such as offshore wave conditions and beach profile (see Stockdon et al., 2006, and Sallenger Jr., 2000, for details), those relations only return approximations as often not all required model input is available or because of inherent model uncertainties. Having said that, the results suggest that dunes along the Delfland coast are sheltered from storm impacts above a beach height of $1.6 \mathrm{~m}$ a.m.s.l. This finding is examined in relation to offshore sea water levels measured by a buoy in close proximity to the Zandmotor mega-scale beach nourishment. Figure 7 shows the probability density curve (which is bimodal because of tidal dynamics) of those sea water levels (in $\mathrm{m} \pm$ m.s.l.), measured every $10 \mathrm{~min}$ from 2011 until 2017. Included are the instances when sea water levels exceeded the apparent $1.6 \mathrm{~m}$ a.m.s.l. boundary height 


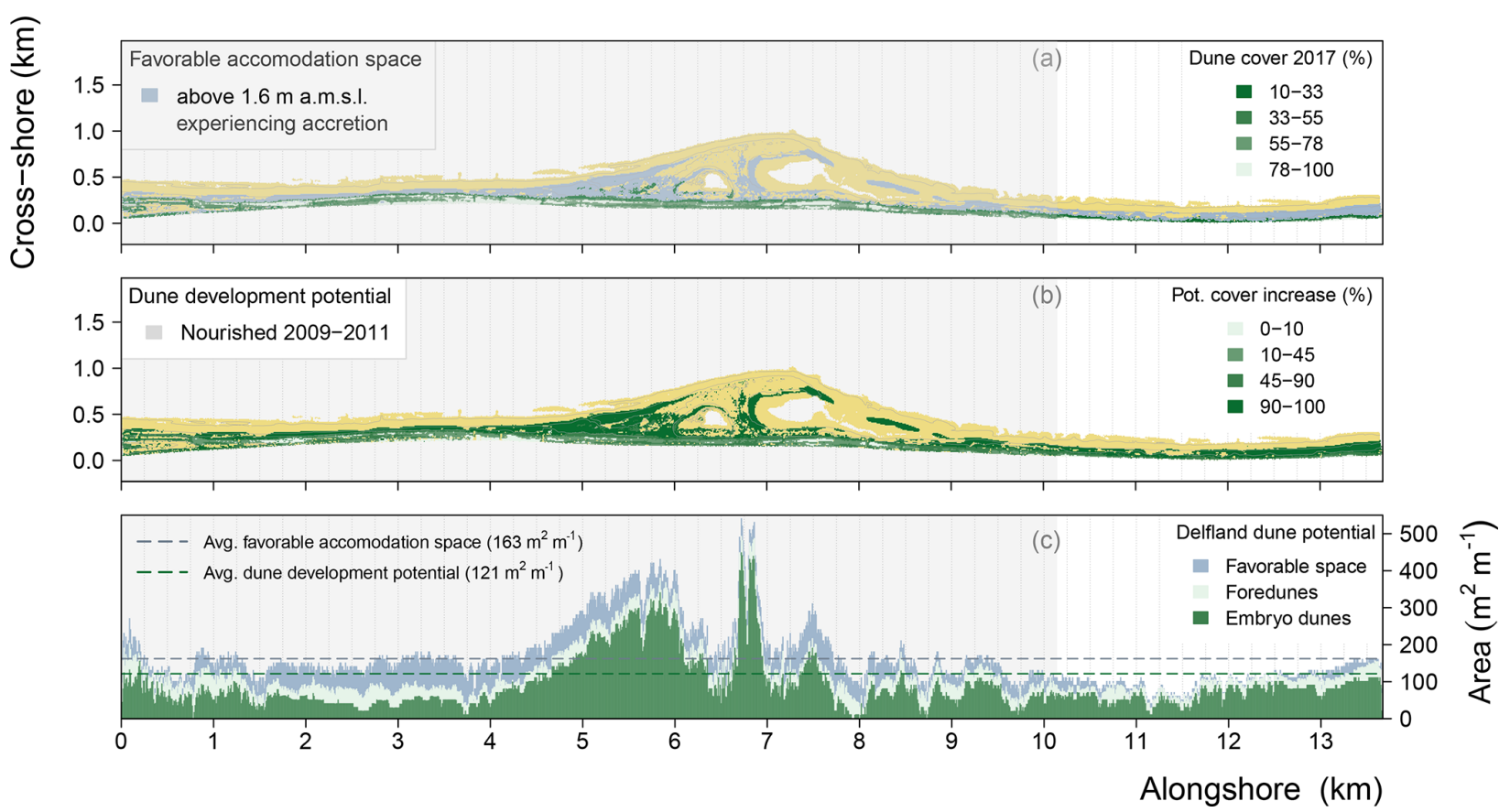

Figure 6. Favorable accommodation space to indicate dune development potential along the Delfland coast. (a) Map of dune cover (\%) by marram grass in 2017 and accommodation space favorable for dune development: located above $1.6 \mathrm{~m}$ a.m.s.1. and experiencing an accretion of sand. (b) Map indicating Delfland coast dune development potential, calculated as the potential of marram grass to increase in cover $(\%)$ based on the accommodation space favorable for dune development and taking into account the dune cover already present in 2017. (c) Alongshore variation of favorable accommodation space and potential for dune development along the Delfland coast $\left(\mathrm{m}^{2} \mathrm{~m}^{-1}\right)$, differentiated for foredunes and embryo dunes.

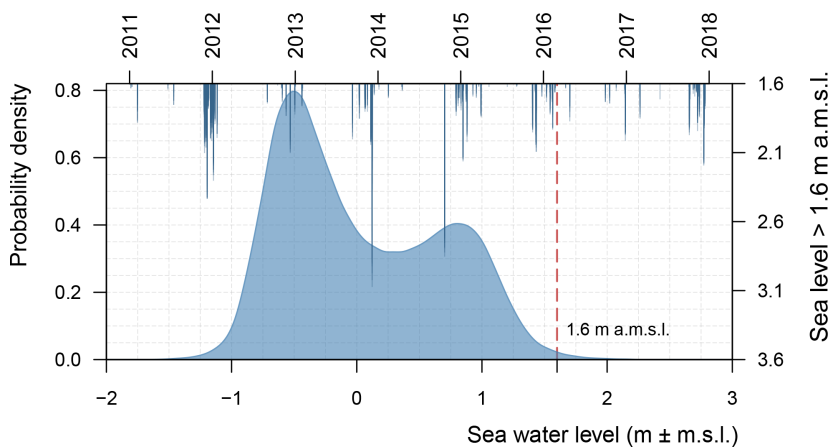

Figure 7. Bimodal probability density curve of sea water levels (in $\mathrm{m} \pm$ m.s.l.) measured by a buoy near Scheveningen since the construction of the Zandmotor in 2011 until 2017. Included are the instances when sea water level exceeded the $1.6 \mathrm{~m}$ a.m.s.l. boundary height for dune development along the Delfland coast.

for dunes to be sheltered from storm impacts. It is clear from Fig. 7 that this did not occur frequently, only during about $0.4 \%$ of the measurements. Those measurements, however, were relatively clustered together, meaning that the boundary height was exceeded over (relatively) prolonged periods of time. Although, over the course of 6 years this happened for no more than 10 full days. On average the exceedance was about $20 \mathrm{~cm}$ up to a sea water level of $1.8 \mathrm{~m}$ a.m.s.l., but on a few occasions sea water levels almost doubled compared to the boundary height to $3.10 \mathrm{~m}$ a.m.s.l. This is excluding the wave run-up onto the beach, which can be significant for natural beaches in the Netherlands. Dependent on whether the beach profile is dissipative or reflective, both Stockdon et al. (2006) and Poortinga et al. (2015) show that wave run-up may reach to heights from 0.85 to $1.45 \mathrm{~m}$ above still water level, which is the level that would occur in the absence of waves. This implies that, since the construction of the Zandmotor in 2011, the Delfland coast may have experienced coastal erosion by storm surge levels reaching heights up to at least $4 \mathrm{~m}$ a.m.s.l.

The observation that in 2017 quite a large number of embryo dunes were present on the beach at heights well below the maximum experienced storm surge levels points to the capacity of established dunes to withstand and recover from hydrodynamic storm impacts as well as to the pivotal role marine dispersal of rhizome fragments likely plays to dune establishment processes. As remarked by various researchers (e.g., Suanez et al., 2012; Feagin et al., 2015; Houser et al., 2015; Van Puijenbroek et al., 2017a, b), the ability of embryo dunes to recover from storm impacts largely depends on the extent to which the above- and belowground structural integrity of marram grass remains intact after a storm 


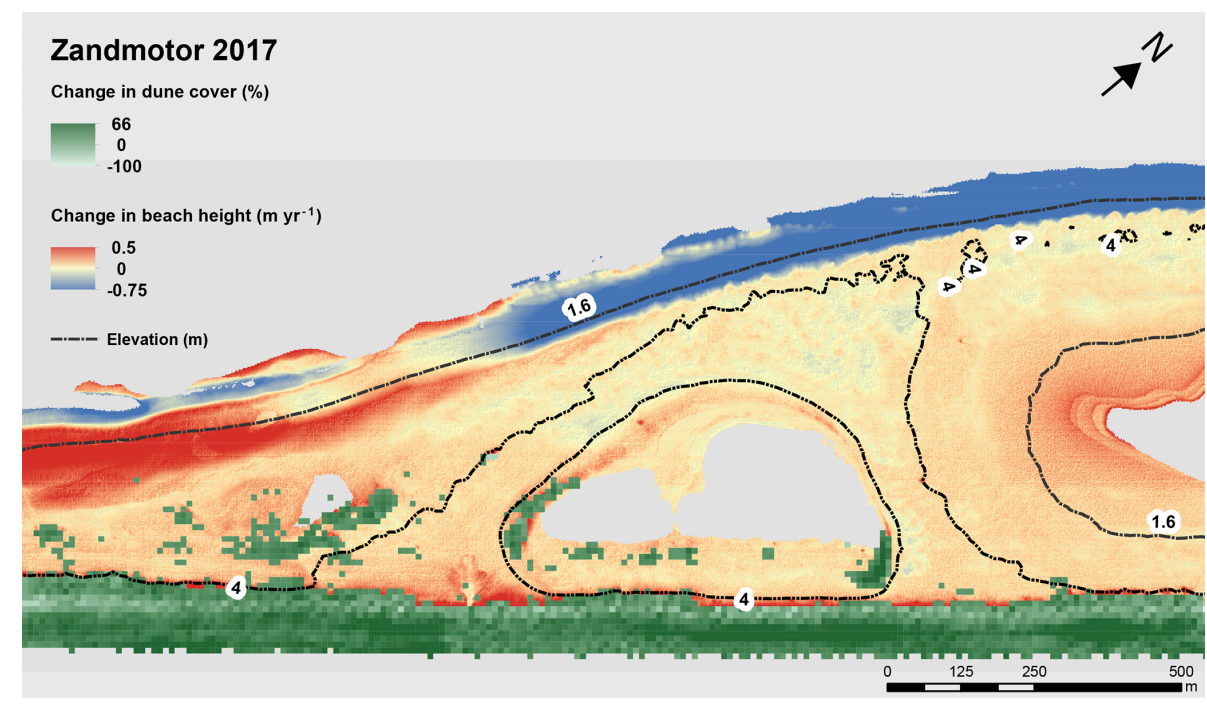

Figure 8. The distribution of (embryo) dunes on the Zandmotor, suggesting a correlation to marine dispersal of rhizome fragments as a large number of embryo dunes are present between the identified boundary height of $1.6 \mathrm{~m}$ a.m.s.l. and the (current) maximum expected storm surge height of $4 \mathrm{~m}$ a.m.s.l.

event. This depends, in turn, on the severity of the storm impacts on the dune, which can be caused by wave erosion (scarping and overwash) and swash inundation (Sallenger Jr., 2000; Hesp and Martínez, 2007). Wave erosion may completely remove all sand from an embryo dune (so it is no longer raised from the beach surface) and have an abrasive effect on the leaves of marram grass, causing either minor damage or complete removal of all aboveground biomass. Most of the belowground root system of marram grass, however, has been observed to largely remain intact after wave scarping or overwash (Feagin et al., 2015). Potential damage of swash inundation to marram grass depends on the duration of the inundation period, but as Vergiev et al. (2013) demonstrate, marram grass displays no visible decomposition of stems, roots or rhizomes after being immersed with sea water for 20 days. This is well beyond the period a beach will be inundated after a storm event, which implies that inundation has a limited, if any, negative effect on the structural integrity of marram grass. Given that storm events occur more frequently in winter, it has been observed that embryo dunes on dissipative beaches undergo a classic seasonal cycle of erosion during the winter and accretion during the summer (Montreuil et al., 2013; Van Puijenbroek et al., 2017b). Their presence on the beach, however, would remain persistent throughout the year and often show a yearly net growth when aeolian supply was sufficient (Anthony et al., 2007; Suanez et al., 2012). This not only indicates that embryo dunes have the capacity to withstand storm impacts and quickly recover to prestorm conditions, but also that the above- and belowground structure of marram grass often remains largely intact after a storm event. Marine forcing, at the same time, has been shown to be an important agent in the dispersal of marram grass rhizome fragments and subsequent dune establishment via clonal growth (Konlechner and Hilton, 2009; Hilton and Konlechner, 2011). The distribution of (embryo) dunes on the southern part of the Zandmotor, as shown in close-up in Fig. 8, suggests a correlation to marine dispersal of rhizome fragments as a large number of embryo dunes are present between the identified boundary height of $1.6 \mathrm{~m}$ a.m.s.l. and the (current) maximum expected storm surge height of $4 \mathrm{~m}$ a.m.s.l. The embryo dunes around the small dune lake, while technically located in the same elevation zone, have likely mostly established by seed germination as the high constructed base of the Zandmotor has completely blocked all storm surge impacts until now. Over the years there has been a steady build-up of a freshwater lens under the Zandmotor and the salinity of the dune lake has significantly decreased as a result (Huizer et al., 2016). This fresh water availability, in combination with moderate burial dynamics, have been shown by Konlechner et al. (2013) to be beneficial to marram grass seed germination and subsequent dune establishment. The specific distribution of embryo dunes around the dune lake may therefore correlate best to seed dispersal by wind coming from the dominant southwestern wind direction, either pushing the seeds over the lake towards the north-east corner of the lake or depositing it on the south-west lee side where the beach slopes downwards towards the lake. In effect, Fig. 8 illustrates that, even though the Zandmotor may provide wide favorable accommodation space and thus a high potential for dune development, the conditions required for successful (natural) dune establishment must also be considered. Having said that, Puijenbroek (2017) showed in a field transplant experiment that planted marram grass (consisting of a rhizome fragment with one 
shoot) thrived on most parts of the Zandmotor except when exposed to direct wave action. This suggests that conditions that limit marram grass growth and subsequent dune development (e.g., high salinity, drought, low nutrient status) are mostly absent on the Zandmotor and likely along the entire Delfland coast.

\subsection{Dune development potential in relation to anthropogenic impacts}

The results highlight the overall importance of the Zandmotor for dune development along the Delfland coast. First, this is because its beach provides very wide favorable accommodation space that therefore supports a high potential for new embryo dune development. And second, because of its sand-feeding effects, the Zandmotor has likely contributed to creating more favorable accommodation space for dune development along the entire Delfland coast. The coastline directly north of the Zandmotor, for example, experienced a significant accumulation of sand between 2013 and 2017 even though it has not been nourished with sand in the years before. Although the amount of sand accumulation was less compared to the coastline that has been nourished between 2009 and 2011, the overall positive sand budget illustrates the intended dynamical nature of the Zandmotor, where its sand is redistributed along the coastline causing a seaward broadening of the beach and dunes. In fact, Fig. 6c suggests that the unnourished northern part of the Delfland coastline supports a higher potential for dune development compared to the nourished southern coastline. In part this may be due to the fact that the Delfland coast is characterized by a net northward sediment transport regime (Van Rijn, 1997), which is reflected in the sand-feeding budget of the Zandmotor. In the first 18 months after its completion, De Schipper et al. (2016) for example show that up to $40 \%$ more sand of Zandmotor was transported in a northward direction rather than southward towards Rotterdam harbor. At the same time, because the 2009-2011 nourishment strategy consisted (for a large part) of foredune reconstruction that included plantings of marram grass, the created favorable accommodation space along the nourished coastline may not accommodate much new dune development. As such, even though the coastline south of the Zandmotor has been reinforced with sand nourishment, it is quite possible for the unnourished northern Delfland coastline to experience more pronounced dune development in the years to come.

Interestingly, however, the positive effect of the Zandmotor on the northern Delfland coastline, in terms of sand accretion, is not reflected in the changes in cover by marram grass between 2016 and 2017. Even though it is shown that the coastline north of the Zandmotor provides ample favorable accommodation space, it appears that the potential for dune development is currently not being realized. There are two main anthropogenic impacts that may hamper dune development along this urbanized coastline, namely persistent disturbances arising from recreation and leisure as well as a (increasingly prevalent) nature management practice that is aimed at remobilizing the dune landscape. Figure 9 gives an overview of total alongshore changes in dune cover by marram grass between 2016 and $2017\left(\mathrm{in} \mathrm{m}^{2} \mathrm{~m}^{-1} \mathrm{yr}^{-1}\right.$ ) and aims to relate it to anthropogenic activities that may impact (both positively and negatively) dune development along the Delfland coast. In the broadest sense, the coastline can be divided first according to whether or not it has recently been nourished with sand and what type of sand nourishment has been implemented. A distinction can be made between the sand nourishment that was carried out between 2009 and 2011 to reinforce most of the Delfland coastline, the nature compensation project Spanjaardsduin implemented at the same time and, finally, the Zandmotor mega-scale beach nourishment that was completed at the end of 2011. Further, within the nourished coastline there is a zone where the dune development appears to lag behind compared to the rest of the nourished coastline. This zone, as Fig. 9b illustrates, can be characterized by a higher concentration of disturbances arising from recreation and leisure. Then, finally, there is the northern part of the Delfland coastline that has not been nourished with sand in recent years. Within this zone, as Fig. 9c shows, relatively large dune areas have been excavated between 2011 and 2013 aimed at rejuvenating the dune landscape by reinitiating aeolian dynamics. In the following paragraphs, each identified zone of the Delfland coast and how dune development potential may be impacted by the various anthropogenic activities are discussed.

As Fig. 9c shows, the overall positive effect of the three sand nourishment schemes on dune development is clearly reflected in the changes in marram grass cover between 2016 and 2017. Within the nourished zone, however, there are three clear dips where the dune cover appears to have decreased over the course of a year. Upon closer inspection it seems that each dip coincides with a beach entrance where the public can enter the beach. A number of natural processes and human activities may be involved here in the observed decline in marram grass cover. First of all, as Fig. 9b shows, the seaward side of a beach entrance is commonly paved with concrete slabs and cuts relatively deep into the stoss slope of the foredune. This, effectively, mimics a through foredune blowout (e.g., Hesp, 2002), in which wind erosion is enhanced because of local wind speed acceleration and pronounced turbulent flow structures such as corkscrew vortices (Hesp and Martínez, 2007). Because the floor is paved, these wind-driven forces will in particular erode (i.e., widen) the slopes of the beach entrance and this susceptibility to lateral erosion may have lead to the observed decline in marram grass cover. Second, as can also be seen in Fig. 9b, there is often a hospitality establishment (e.g., a beach bar or restaurant) directly beside a beach entrance. And although their placement on the beach is often seasonal, their presence is numerous. In the summer of 2017, for example, only 3 of the 23 beach entrances along the Delfland coast did not have one 

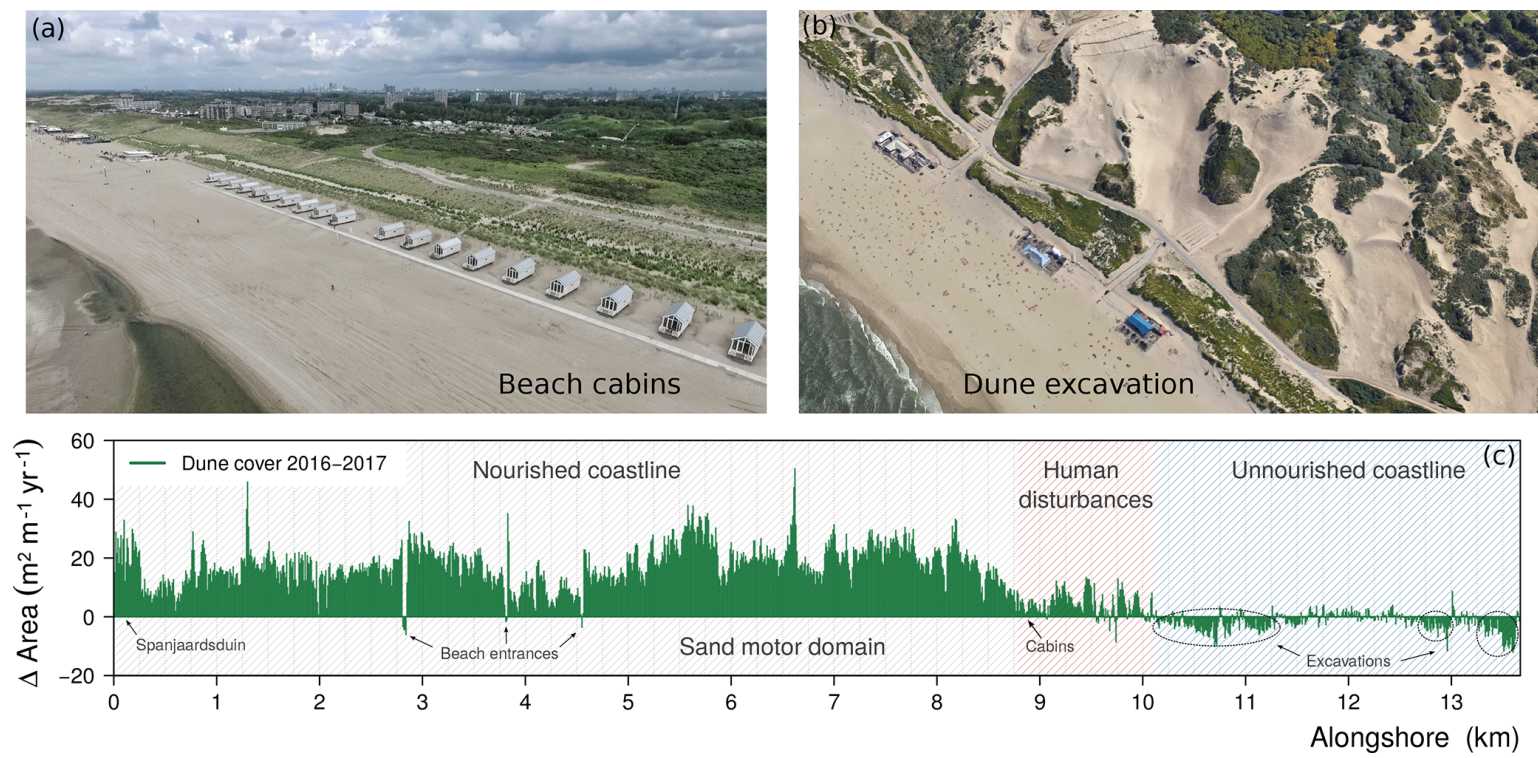

Figure 9. Overview of total alongshore changes in dune cover by marram grass between 2016 and 2017 (in $\mathrm{m}^{2} \mathrm{~m}^{-1} \mathrm{yr}^{-1}$ ) in relation to anthropogenic activities that impact (positively and negatively) dune development along the Delfland coast. Aerial photographs courtesy of René Oudshoorn (a) and Google Maps (b).

or more hospitality establishments directly placed besides it. Perhaps not coincidentally, two of those three entrances gave access to the more isolated parts of the Zandmotor. The presence of hospitality establishments puts additional pressure on the dunes as people may flock around the beach entrances and motorized vehicles are more common, e.g., to resupply the establishment. Even though walking or driving in the foredunes is prohibited along the Delfland coast, several studies (e.g., Andersen, 1995; Anders and Leatherman, 1987) show that vehicles and people on the beach may have a significant negative effect on dune development.

At the same time, as laid out in more detail by Jackson and Nordstrom (2011), the structure of the hospitality establishment itself may alter (i.e., block) aeolian transport from the beach and retard foredune development. This plays an even larger role in the nourished zone north of the Zandmotor where, besides a large number of hospitality establishments, a high amount of seasonal beach cabins are also placed along the toe of the foredunes from March until October (from 2016 onward). Their placement close together, as Fig. 9a shows, has the additional effect that the airflow can constrict and accelerate between the beach cabins, which increases the likelihood of local scour resulting in aeolian deposition farther landward (Nordstrom, 2004). Although in some instances this may actually be beneficial to the foredunes, the clear decline in cover by marram grass (see Fig. 9c) indicates that the placement of beach cabins had an overall negative impact on dune development between 2016 and 2017. And while the beach cabins were in fact raised slightly from the surface $(\sim 50 \mathrm{~cm})$, Nordstrom and McCluskey (1984) show that such a modest height may not have been sufficient to minimize interference with the wind flow and resultant aeolian dynamics. Further, another important anthropogenic disturbance with a highly negative impact to dune development is that the beach directly north of the Zandmotor is mechanically raked during the summer to remove wrack line material and human litter. Even though it is a common practice to accommodate beach recreation (Jackson and Nordstrom, 2011), this severely hampers embryo dunes from establishing themselves on the beach. Not only can the machinery destroy any sprouting seedlings or rhizomes of marram grass, the removal of wrack deposits also deprives marram grass from potential hospitable locations to establish itself on the beach (Kelly, 2014). As a result, these anthropogenic disturbances combined have likely contributed to reduced dune development compared to the rest of the nourished Delfland coastline.

Then, as Figs. 9c and 4e show, the decrease in marram grass cover along the unnourished northern part of the Delfland coastline suggests that the foredunes have been in decline between 2016 and 2017. This is unexpected considering the positive sand-feeding effect of the Zandmotor on this stretch of coastline. Upon closer inspection, the main candidates for the observed foredune decline are a number of dune excavations aimed at rejuvenating the dune landscape. When the focus of Dutch coastal policy widened, to also include preserving the spatial quality and natural values of the coastal zone, it was recognized that traditional flood safety measures had led to over-stabilized dune systems that were characterized by a markedly reduced biodiversity compared to younger and more dynamic dune systems (e.g., van Dorp et al., 1985; Provoost et al., 2011). For that reason, in places 
where coastal safety could be guaranteed, remobilizing dune systems by removal of dune vegetation and topsoil has become a key management practice for maintaining a high biodiversity in the dune landscape. Reinitiating aeolian dynamics is hereto essential, as deflation and deposition zones creates habitat diversity and renewed opportunities for specialized pioneer vegetation species (e.g., Arens et al., 2013). Nowadays, in order to maintain or even increase dune mobility, the rejuvenated dune systems are often connected to the beach and foredunes through the excavation of foredune notches. This has been shown to result in a sustained input of wind-blown calcareous beach sand and more diverse living conditions for pioneer vegetation, e.g., due to higher levels of sand burial, wind speeds or salt spray (Riksen et al., 2016; Ruessink et al., 2017). However, as Fig. 9c shows, dune excavation practices appear to adversely affect foredune development. While there were no foredune notches explicitly excavated along the Delfland coast, Fig. $9 \mathrm{~b}$ shows that the paved beach entrances may similarly act as conduits for aeolian transport into the dune excavations. As a result it is quite possible that the narrow foredunes in front of the excavated dune are experiencing a net deflation of sand that negatively affects the growth of marram grass (e.g., by root exposure). Sand deposition then likely occurs deeper landward where no marram grass is presently growing to benefit from an increase in sand burial. Marram grass cover, as a result, has been in decline between 2016 and 2017, indicating a decline in the foredunes as well. However, with the Zandmotor feeding the coastline and providing an effective flood defense, this localized foredune decline should not pose an imminent threat to coastal safety.

\section{Conclusions}

This paper examined to what extent the Zandmotor has contributed to creating accommodation space along the Delfland coast favorable for dune development, i.e., accommodation space that is sheltered from frequent storm impacts and experiencing a steady accumulation of wind-blown sand. Comparing the presence of dunes in 2017 to its elevation indicates that dunes are sheltered from storm surges above a height of $1.6 \mathrm{~m}$ a.m.s.l. Comparing the changes in dune cover by marram grass from 2016 to 2017 to the average yearly change in dune height between 2013 and 2017 demonstrates that dunes were almost exclusively present in accreting areas. As such, even though its design may not be optimal for successful marram grass establishment, the results highlight the overall importance of the Zandmotor to dune development potential:

- Compared to the rest of the Delfland coast, the supratidal beach of the Zandmotor provides very wide favorable accommodation space and therefore supports a high potential for new embryo dunes to develop.

- Because of its sand-feeding effects, the Zandmotor will likely contribute to creating more favorable accommo- dation space for dune development along the entire Delfland coast.

However, because of persistent anthropogenic disturbances arising from recreation and nature management practices, dune development along this urbanized coastline may not reach its full potential. This should not be too alarming, though, as the Zandmotor mega-scale beach nourishment is set to ensure the safety of the Delfland coast for years to come.

Data availability. Coastal lidar data are made available under a Creative Commons Zero (CC0) statement by Rijkswaterstaat, the Dutch executive agency of the Ministry of Infrastructure and Water Management. Sentinel-2 satellite imagery is made available by the European Space Agency (ESA) in agreement with the Copernicus Sentinel data policy.

Author contributions. CN and MR conceived and developed the paper idea. $\mathrm{CN}$ performed the data analysis and both authors contributed to writing and editing of the paper.

Competing interests. The authors declare that they have no conflict of interest.

Acknowledgements. The research was carried out within the program "Nature-driven nourishment of coastal systems" (NatureCoast) and funded by technology foundation STW (grant 12686), applied science division of the Netherlands Organization for Scientific Research (NWO).

Edited by: Andreas Baas

Reviewed by: Michael Hilton and Irene Delgado-Fernandez

\section{References}

Anders, F. J. and Leatherman, S. P.: Effects of off-road vehicles on coastal foredunes at Fire Island, New York, USA, Environ. Manage., 11, 45-52, 1987.

Andersen, U. V.: Resistance of Danish coastal vegetation types to human trampling, Biol. Conserv., 71, 223-230, 1995.

Anthony, E. J.: Storms, shoreface morphodynamics, sand supply, and the accretion and erosion of coastal dune barriers in the southern North Sea, Geomorphology, 199, 8-21, 2013.

Anthony, E. J., Vanhée, S., and Ruz, M.-H.: Embryo dune development on a large, actively accreting macrotidal beach: Calais, North Sea coast of France, Earth Surf. Process. Landf., 32, 631636, 2007.

Arens, S. M.: Patterns of sand transport on vegetated foredunes, Geomorphology, 17, 339-350, 1996.

Arens, S. M., Kaam-Peters, V., and Van Boxel, J. H.: Air flow over foredunes and implications for sand transport, Earth Surf. Process. Landf., 20, 315-332, 1995. 
Arens, S. M., Mulder, J. P., Slings, Q. L., Geelen, L. H., and Damsma, P.: Dynamic dune management, integrating objectives of nature development and coastal safety: examples from the Netherlands, Geomorphology, 199, 205-213, 2013.

Baas, A. C. W. and Nield, J. M.: Ecogeomorphic state variables and phase-space construction for quantifying the evolution of vegetated aeolian landscapes, Earth Surf. Process. Landf., 35, 717731, 2010.

Claudino-Sales, V., Wang, P., and Horwitz, M. H.: Factors controlling the survival of coastal dunes during multiple hurricane impacts in 2004 and 2005: Santa Rosa barrier island, Florida, Geomorphology, 95, 295-315, 2008.

Davidson-Arnott, R., Hesp, P., Ollerhead, J., Walker, I., Bauer, B., Delgado-Fernandez, I., and Smyth, T.: Sediment budget controls on foredune height: Comparing simulation model results with field data, Earth Surf. Process. Landf., 43, 1798-1810, https://doi.org/10.1002/esp.4354, 2018.

De Jong, B., Keijsers, J. G. S., Riksen, M. J. P. M., Krol, J., and Slim, P. A.: Soft Engineering vs. a Dynamic Approach in Coastal Dune Management: A Case Study on the North Sea Barrier Island of Ameland, The Netherlands, J. Coast. Res., 30, 670-684, https://doi.org/10.2112/JCOASTRES-D-13-00125.1, 2014.

De Schipper, M. A., De Vries, S., Ruessink, G., De Zeeuw, R. C., Rutten, J., Van Gelder-Maas, C., and Stive, M. J. F.: Initial spreading of a mega feeder nourishment: Observations of the Sand Engine pilot project, Coast. Eng., 111, 23-38, 2016.

De Vriend, H. J., van Koningsveld, M., Aarninkhof, S. G., De Vries, M. B., and Baptist, M. J.: Sustainable hydraulic engineering through building with nature, J. Hydro.-Environ. Res., 9, 159171,2015

Disraeli, D. J.: The effect of sand deposits on the growth and morphology of Ammophila breviligulata, The J. Ecol., 72, 145-154, 1984.

Drusch, M., Del Bello, U., Carlier, S., Colin, O., Fernandez, V., Gascon, F., Hoersch, B., Isola, C., Laberinti, P., Martimort, P., Meygret, A., Spoto, F., Sy, O., Marchese, F., and Bargellini, P.: Sentinel-2: ESA's optical high-resolution mission for GMES operational services, Remote Sens. Environ., 120, 25-36, 2012.

Durán, O. and Moore, L. J.: Vegetation controls on the maximum size of coastal dunes, Proc. Natl. Acad. Sci. USA, 110, 1721717222, 2013.

Feagin, R. A., Figlus, J., Zinnert, J. C., Sigren, J., Martínez, M. L., Silva, R., Smith, W. K., Cox, D., Young, D. R., and Carter, G.: Going with the flow or against the grain? The promise of vegetation for protecting beaches, dunes, and barrier islands from erosion, Front. Ecol. Environ., 13, 203-210, 2015.

Fiselier, J.: Milieueffectrapportage Zandmotor Delflandse kust, MER rapport door DHV in opdracht van provincie Zuid Holland, 2010.

Gemmell, A. R., Greig-Smith, P., and Gimingham, C. H.: A note on the behaviour of Ammophila arenaria (L.) Link, in relation to sand-dune formation, in: Transactions of the Botanical Society of Edinburgh, Vol. 36, 132-136, Taylor \& Francis, 1953.

Hardisty, J.: Beach and nearshore sediment transport, Sediment transport and depositional processes. Blackwell, London, UK, 216-255, 1994.

Hartigan, J. A. and Wong, M. A.: Algorithm AS 136: A k-means clustering algorithm, J. Roy. Stat. Soc C, 28, 100-108, 1979.
Hesp, P.: Foredunes and blowouts: initiation, geomorphology and dynamics, Geomorphology, 48, 245-268, 2002.

Hesp, P. A.: A review of biological and geomorphological processes involved in the initiation and development of incipient foredunes, Proc. Roy. Soc. Edinburgh B, 96, 181-201, 1989.

Hesp, P. A.: Ecological processes and plant adaptations on coastal dunes, J. Arid Environ., 21, 65-61, 1991.

Hesp, P. A. and Martínez, M. L.: Disturbance processes and dynamics in coastal dunes, Plant disturbance ecology: the process and the response, 215-247, 2007.

Hilton, M. and Konlechner, T.: Incipient Foredunes Developed from Marine-dispersed Rhizome of Ammophilia arenaria, J. Coast. Res., 64, 288-292, 2011.

Hoonhout, B. and De Vries, S.: Aeolian sediment supply at a mega nourishment, Coast. Eng., 123, 11-20, 2017.

Houser, C., Hapke, C., and Hamilton, S.: Controls on coastal dune morphology, shoreline erosion and barrier island response to extreme storms, Geomorphology, 100, 223-240, 2008.

Houser, C., Wernette, P., Rentschlar, E., Jones, H., Hammond, B., and Trimble, S.: Post-storm beach and dune recovery: Implications for barrier island resilience, Geomorphology, 234, 54-63, 2015.

Huiskes, A. H. L.: Ammophila arenaria (L.) Link (Psamma arenaria (L.) Roem. et Schult.; Calamgrostis arenaria (L.) Roth), J. Ecol., 67, 363-382, 1979.

Huizer, S., Oude Essink, G. H. P., and Bierkens, M. F. P.: Fresh groundwater resources in a large sand replenishment, Hydrol. Earth Syst. Sci., 20, 3149-3166, https://doi.org/10.5194/hess-203149-2016, 2016.

Jackson, N. L. and Nordstrom, K. F.: Aeolian sediment transport and landforms in managed coastal systems: a review, Aeol. Res., 3, 181-196, 2011.

Jervey, M.: Quantitative geological modeling of siliciclastic rock sequences and their seismic expression, 1988.

Keijsers, J., De Groot, A., and Riksen, M.: Vegetation and sedimentation on coastal foredunes, Geomorphology, 228, 723-734, 2015a.

Keijsers, J. G. S., Giardino, A., Poortinga, A., Mulder, J. P. M., Riksen, M. J. P. M., and Santinelli, G.: Adaptation strategies to maintain dunes as flexible coastal flood defense in The Netherlands, Mitigation and Adaptation Strategies for Global Change, 20, 913-928, 2015b.

Keijsers, J. G. S., De Groot, A. V., and Riksen, M. J. P. M.: Modeling the biogeomorphic evolution of coastal dunes in response to climate change, J. Geophys. Res.-Earth Surf., 121, 1161-1181, 2016.

Kelly, J. F.: Effects of human activities (raking, scraping, off-road vehicles) and natural resource protections on the spatial distribution of beach vegetation and related shoreline features in New Jersey, J. Coast. Conserv., 18, 383-398, 2014.

Konlechner, T. and Hilton, M.: The potential for marine dispersal of Ammophila arenaria (Marram Grass) rhizome in New Zealand, Proceedings of the 10th International Coastal Symposium ICS 2009, J. Coast. Res., SI No. 56, 434-437, 2009.

Konlechner, T. M., Hilton, M. J., and Orlovich, D. A.: Accommodation space limits plant invasion: Ammophila arenaria survival on New Zealand beaches, J. Coast. Conserv., 17, 463-472, 2013.

Lithgow, D., Martínez, M., Gallego-Fernández, J., Hesp, P., Flores, P., Gachuz, S., Rodríguez-Revelo, N., Jiménez-Orocio, 
O., Mendoza-González, G., and Álvarez-Molina, L.: Linking restoration ecology with coastal dune restoration, Geomorphology, 199, 214-224, 2013.

Lu, D., Moran, E., and Batistella, M.: Linear mixture model applied to Amazonian vegetation classification, Remote Sens. Environ., 87, 456-469, 2003.

Lucas, N. S., Shanmugam, S., and Barnsley, M.: Sub-pixel habitat mapping of a costal dune ecosystem, Appl. Geogr., 22, 253-270, 2002.

Luijendijk, A. P., Ranasinghe, R., de Schipper, M. A., Huisman, B. A., Swinkels, C. M., Walstra, D. J., and Stive, M. J.: The initial morphological response of the Sand Engine: A process-based modelling study, Coast. Eng., 119, 1-14, 2017.

Maun, M. A.: Adaptations of plants to burial in coastal sand dunes, Can. J. Botany, 76, 713-738, 1998.

Maun, M. A. and Lapierre, J.: The effects of burial by sand on Ammophila breviligulata, The J. Ecol., 72, 827-839, 1984.

Montreuil, A.-L., Bullard, J. E., Chandler, J. H., and Millett, J.: Decadal and seasonal development of embryo dunes on an accreting macrotidal beach: North Lincolnshire, UK, Earth Surf. Process. Landf., 38, 1851-1868, 2013.

Mulder, J. P. and Tonnon, P. K.: Sand Engine: Background and design of a mega-nourishment pilot in the Netherlands, Coast. Eng. Proc., 1, 35, 2011.

Nolet, C., van Puijenbroek, M., Suomalainen, J., Limpens, J., and Riksen, M.: UAV-imaging to model growth response of marram grass to sand burial: Implications for coastal dune development, Aeolian Res., 31, 50-61, https://doi.org/10.1016/j.aeolia.2017.08.006, 2017.

Nordstrom, K. F.: Beaches and dunes of developed coasts, Cambridge University Press, 2004.

Nordstrom, K. F. and McCluskey, J. M.: Considerations for control of house construction in coastal dunes, Coast. Manage., 12, 385402, 1984.

Pettorelli, N., Vik, J. O., Mysterud, A., Gaillard, J.-M., Tucker, C. J., and Stenseth, N. C.: Using the satellite-derived NDVI to assess ecological responses to environmental change, Trends Ecol. Evolut., 20, 503-510, 2005.

Poortinga, A., Keijsers, J., Visser, S., Riksen, M., and Baas, A.: Temporal and spatial variability in event scale aeolian transport on Ameland, The Netherlands, Geo. Res. J., 5, 23-35, 2015.

Provoost, S., Jones, M. L. M., and Edmondson, S. E.: Changes in landscape and vegetation of coastal dunes in northwest Europe: a review, J. Coast. Conserv., 15, 207-226, 2011.

Puijenbroek, M. E.: Dunes, above and beyond, Ph.D. thesis, Wageningen University, 2017.

Ranwell, D. S.: Ecology of salt marshes and sand dunes, Vol. 258, Chapman and Hall London, 1972.

Riksen, M. J., Goossens, D., Huiskes, H. P., Krol, J., and Slim, P. A.: Constructing notches in foredunes: Effect on sediment dynamics in the dune hinterland, Geomorphology, 253, 340-352, 2016.

Rouse Jr., J. W., Haas, R. H., Schell, J. A., and Deering, D. W.: Monitoring vegetation systems in the Great Plains with ERTS, NASA special publication, 351, 309, 1974.

Ruessink, B., Arens, S., Kuipers, M., and Donker, J.: Coastal dune dynamics in response to excavated foredune notches, Aeolian Res., 3, 3-17, 2017.
Ruggiero, P., Komar, P. D., McDougal, W. G., Marra, J. J., and Beach, R. A.: Wave runup, extreme water levels and the erosion of properties backing beaches, J. Coast. Res., 17, 407-419, 2001.

Sallenger Jr., A. H.: Storm impact scale for barrier islands, J. Coast. Res., 16, 890-895, 2000.

Settle, J. and Drake, N.: Linear mixing and the estimation of ground cover proportions, Int. J. Remote Sens., 14, 1159-1177, 1993.

Short, A. and Hesp, P.: Wave, beach and dune interactions in southeastern Australia, Mar. Geol., 48, 259-284, 1982.

Smith, M. O., Johnson, P. E., and Adams, J. B.: Quantitative determination of mineral types and abundances from reflectance spectra using principal components analysis, J. Geophys. Res.-Solid Earth, 90, 797-804, 1985.

Stive, M. J., De Schipper, M. A., Luijendijk, A. P., Aarninkhof, S. G. J., Van Gelder-Maas, C., Van Thiel de Vries, J. S. M., de Vries, S., Henriquez, M., Marx, S., and Ranasinghe, R.: A new alternative to saving our beaches from sea-level rise: The sand engine, J. Coast. Res., 29, 1001-1008, 2013.

Stockdon, H. F., Holman, R. A., Howd, P. A., and Sallenger Jr., A. H.: Empirical parameterization of setup, swash, and runup, Coast. Eng., 53, 573-588, 2006.

Suanez, S., Cariolet, J.-M., Cancouët, R., Ardhuin, F., and Delacourt, C.: Dune recovery after storm erosion on a high-energy beach: Vougot Beach, Brittany (France), Geomorphology, 139, 16-33, 2012.

Temmerman, S., Meire, P., Bouma, T. J., Herman, P. M. J., Ysebaert, T., and De Vriend, H. J.: Ecosystem-based coastal defence in the face of global change, Nature, 504, 79-83, 2013.

Theseira, M., Thomas, G., Taylor, J., Gemmell, F., and Varjo, J.: Sensitivity of mixture modelling to end-member selection, Int. J. Remote Sens., 24, 1559-1575, 2003.

Tucker, C. J.: Red and photographic infrared linear combinations for monitoring vegetation, Remote Sens. Environ., 8, 127-150, 1979.

Van der Meulen, F., Van der Valk, B., Baars, L., Schoor, E., and Van Woerden, H.: Development of new dunes in the Dutch Delta: nature compensation and "building with nature", J. Coast. Conserv., 18, 505-513, 2014.

Van der Putten, W. H., Van Dijk, C., and Troelstra, S. R.: Biotic soil factors affecting the growth and development of Ammophila arenaria, Oecologia, 76, 313-320, 1988.

Van der Wal, D.: Beach-dune interactions in nourishment areas along the Dutch coast, J. Coast. Res., 20, 317-325, 2004.

van Dorp, D., Boot, R., and van der Maarel, E.: Vegetation succession on the dunes near Oostvoorne, The Netherlands, since 1934, interpreted from air photographs and vegetation maps, Vegetatio, 58, 123-136, 1985.

Van Koningsveld, M. and Mulder, J. P. M.: Sustainable coastal policy developments in the Netherlands. A systematic approach revealed, J. Coast. Res., 20, 375-385, 2004.

Van Koningsveld, M., Otten, C., and Mulder, J.: Dunes: the Netherlands soft but secure sea defences, in: Proceedings 18th World dredging congress, Florida USA, WODA, 2007.

Van Puijenbroek, M. E., Limpens, J., De Groot, A. V., Riksen, M. J., Gleichman, M., Slim, P. A., Dobben, H. F., and Berendse, F.: Embryo dune development drivers: beach morphology, growing season precipitation, and storms, Earth Surf. Process. Landf., 42, 1733-1744, 2017a. 
van Puijenbroek, M. E. B., Nolet, C., de Groot, A. V., Suomalainen, J. M., Riksen, M. J. P. M., Berendse, F., and Limpens, J.: Exploring the contributions of vegetation and dune size to early dune development using unmanned aerial vehicle (UAV) imaging, Biogeosciences, 14, 5533-5549, https://doi.org/10.5194/bg14-5533-2017, 2017.

Van Rijn, L. C.: Sediment transport and budget of the central coastal zone of Holland, Coast. Eng., 32, 61-90, 1997.

Van Slobbe, E., De Vriend, H., Aarninkhof, S., Lulofs, K., De Vries, M., and Dircke, P.: Building with Nature: in search of resilient storm surge protection strategies, Nat. Hazards, 66, 1461-1480, 2013.

Vellinga, P.: Beach and dune erosion during storm surges, Coast. Eng., 6, 361-387, 1982.
Vergiev, S., Filipova-Marinova, M., Trifonova, E., Kotsev, I., and Pavlov, D.: The impact of sea water immersion on the viability of psammophilous species Leymus racemosus subsp. sabulosus and Ammophila arenaria, CR Acad. Bulg. Sci., 66, 212-216, 2013.

Zarnetske, P. L., Hacker, S. D., Seabloom, E. W., Ruggiero, P., Killian, J. R., Maddux, T. B., and Cox, D.: Biophysical feedback mediates effects of invasive grasses on coastal dune shape, Ecology, 93, 1439-1450, 2012.

Zhang, L. and Baas, A. C.: Mapping functional vegetation abundance in a coastal dune environment using a combination of LSMA and MLC: a case study at Kenfig NNR, Wales, Int. J. Remote Sens., 33, 5043-5071, 2012. 